\title{
Management Strategy in Maintaining a Good Relationship with Stakeholders by Implementing the Corporate Social Responsibility (CSR) Program at PT Pertamina (Persero) Refinery Unit IV Cilacap
}

\author{
M Romi Bahtiar ${ }^{\mathrm{a}}$, Setyo Riyanto ${ }^{\mathrm{b}}$ \\ Departement of Economic and Business \\ UNIVERSITY OF MERCU BUANA JAKARTA
}

\begin{abstract}
PT Pertamina (Persero) Refinery Unit IV Cilacap, is the largest refinery in Indonesia which has a production capacity of 348,000 barrels per day and this refinery is very strategic because it supplies $34 \%$ of national fuel needs or $60 \%$ of fuel needs in Java. In implementing its CSR program, it has 4 pillars, namely Healthy Pertamina, Smart Pertamina, Green Pertamina and Berdikari Pertamina, each of which has its own concentration. The application of CSR is not only based on requirements, seeing the real condition of the surrounding community. The CSR program is an environmental social responsibility to the surrounding community from the company's operational activities. In the implementation of CSR programs in the Refinery Unit IV Cilacap, it was carried out with the University of Gajah Mada in Yogyakarta such as the implementation of social mapping and personnel assistance such as the Community Development Officer (CDO). The CSR Implementation Strategy Program is prioritized for communities around Ring 1 or those that receive direct impacts from refinery operations. The implementation of CSR is also done through focus group discussions with relevant stakeholders such as the Cilacap Regency Government, Community Social Institutions, and also other companies related to the work area. Where the implementation of CSR must be interconnected and synergized so that the Government's short-term and long-term programs to advance the budget and development or the Human Development Index (HDI) can be implemented properly. This research program is a CSR implementation program at PT. Pertamina (Persero) RU IV Cilacap can help a good relationship with stakeholders around the operational business can run well and the surrounding community benefits from the existence of CSR programs
\end{abstract}

Keywords:- Strategic Management; Corporate Social Responsisibilty; Pertamina RU IV Cilacap; Stakeholders.

\section{INTRODUCTION}

Corporate Social Responsibility (CSR) is a form of corporate concern to act in their own ways in contributing to solving social problems such as job vacancies, health, education, and the community. Corporate social responsibility in Indonesia is regulated in Law no. 40 of 2007 concerning social and environmental responsibility of the company is limited and updated with the issuance of PP No. 47 of 2012. From existing regulations, each company has an obligation to engage with the community around the company. In other words, the existence of a company that will have both positive and negative impacts will have an impact on the company's sustainability. The realization of CSR is in the form of company programs given to the community. These programs are carried out in several stages, such as social mapping, focus group discussions, plan of action, action and facilitation, and evaluation. The stages in the implementation of CSR programs are carried out with various CSR strategies and models, given the resources owned by the company. Like the company PT. Pertamina (Persero) Refinery Unit IV Cilacap in Cilacap Regency, Central Java. The company develops its own strategies and models for implementing CSR in order to achieve the desired goals of the company.

The problem faced in implementing CSR in PT Pertamina (Persero) Refinery Unit IV Cilacap is how to synergize well with relevant stakeholders where there are Community Social Institutions (NGOs), the Government of Cilacap Regency and also residents around oil refineries who really feel the impact of the presence Pertamina's operational business activities. Every day the residents feel an unpleasant odor, noise and sometimes water pollution from leaking waste. Sometimes people block access to refineries and demonstrations in front of the office, they demand compensation due to operational activities caused by oil refineries. 


\section{LITERATURE REVIEW}

Corporate Social Resposibility (CSR) is a mechanism for a company to voluntarily integrate attention to the social environment into its operations and interactions with stakeholders, which exceeds social responsibility in the legal field. Friedman's opinion in Suharto (2008) states that the main goal of a corporation is to simply get profit is increasingly abandoned. Instead the triple bottom line concept (profit, planet, people) initiated by John Elkington is increasingly entering the mainstream of business ethics.

Basically, CSR is the company's responsibility towards the stakeholders, and also the company's responsibility towards the shareholders. Actually, up to now the definition of CSR is still diverse and has different definitions from one another. Globally, CSR is a commitment of the company to have a responsibility to consumers, employees, shareholders, the community and the environment in all aspects of the company's operations. CSR is closely related to "sustainable development", where there is an argument that a company in carrying out its activities must base its decisions not only on financial factors, such as profits or dividends but also must be based on social and environmental consequences for the present and long term.

The definition of CSR according to (Edi Suharto, $2007 b$ ) is "the concern of companies that set aside some of its profits (profits) for the benefit of human development (people) and the environment (planet) in a sustainable manner based on appropriate and professional procedures". The definition of CSR according to Ismail Solihin, is "one of the forms of corporate responsibility towards stakeholders". According to (Gunawan Widjaja and Yeremia Ardi Pratama, 2008) CSR has not defined CSR in their own opinion, but in the book defining CSR refers to the contents of Article 1 Item 3 of Company Law, where that TJSL is an obligation. In connection with 3 (three) definitions of CSR as follows:

$>$ Take social action including environmental stewardship, more than the boundaries required in legislation.

$>$ Business commitment to act ethically, operate legally, and contribute to economic improvement along with improving the quality of life of employees and their families, local communities and the wider community.

$>$ Business commitment to contribute to sustainable economic development, working with company employees, the employee's family, the following local community and the community as a whole in order to improve the quality of life

According to Setyo Riyanto, Eny Ariyanto and Lukertina. (2019), in the current era of disruption, the most successful companies are those who accept that they are the most entitled to valuable assets. In connection with the company increasing the company's results, so that compiling it to the community will immediately show the company's identity. Setyo Riyanto and Lukertina. (2019), said that good corporate governance will show the quality of productivity of its employees, so the role of employees is also important to build the company's image in the eyes of the public.

CSR (Corporate Social Responsibility) is closely related to "sustainable development", where there is an argument that a company in carrying out its activities must base its decisions not only on financial factors, such as profits or dividends but must also be based on social and environmental consequences for the present and for the period long. The function of CSR is to carry out its social and corporate duties and responsibilities. So that the CSR programs that are made are good activities that are prepared based on a work plan for a certain period of time as well as proposals / cooperation offer letters that are in accordance with the work program and have been approved by the leadership. Those referred to as recipients of CSR programs are those who enjoy or accept CSR programs. Therefore, the recipient of the CSR Program is the community / agency / institution, etc. who submit work plans (proposals) and meet the criteria in accordance with applicable regulations, and have gone through a selection (evaluation) process by the CSR function. Proposal here is defined as a request for cooperation or assistance submitted by the applicant (community / Institution / Agency etc.) to the Company.

The role of CSR (Corporate Social Responsibility) according to The World Business Council for Sustainable Development (WBCSD), Corporate Social Responsibility or corporate social responsibility is defined as a business commitment to contribute to sustainable economic development, through cooperation with employees and their representatives, families they, the local community and the general public to improve the quality of life in ways that benefit both their own business and development. Corporate social responsibility is expressed in a report called Sustainability Reporting. Sustainability Reporting is reporting on economic, environmental and social policies, the influence and performance of an organization and its products in the context of sustainable development. Sustainability Reporting includes reporting on economic, environmental and social influences on organizational performance.

\section{METHODS}

This research journal is based on experience as a CSR staff in Refinery Unit IV Cilacap. In the experience that has been experienced for the implementation of CSR in the Cilacap Refinery Unit IV is quite good, this can be seen from the programs that have been running from year to year so as to obtain a Proper Gold from the Ministry of Environment in 2019. So that in the coming year it is expected to maintain and enhance CSR programs with more innovation being carried out on each aspect of the assessment. 


\section{RESULTS}

Pertamina RU IV Cilacap, in its business operational activities, namely processing crude oil into finished oil which is ready for sale, makes a lot of business from the surrounding community. Where they live side by side and earn a living attending oil refineries. For example there are those who become fishermen, and farmers like fish, shrimp and crabs. Sometimes a little overflow of waste that flows into the river So the surface of the river becomes interested, and in the end the community organizes to the Public Relations of Pertamina. Besides the unpleasant odor is also often a problem, every round if the direction of the wind that does not cause unpleasant odors. The sound of production machines sometimes heard could be heard reaching residents' houses, causing residents to take inconvenience.

PT. Pertamina RU IV Cilacap has been trying to control environmental pollution, and has proven successful in getting a Green Proper rating, meaning that the company has run its business in accordance with standards and is able to empower local residents to take an active role in protecting the environment.

In the implementation of the CSR program, PT Pertamina RU IV Cilacap cooperates with UGM in order to carry out a social mapping to find out maps of the social conditions of affected communities where the results will be outlined in the recommendations of what needs to be done to achieve sustainability of business operations that are able to run in harmony with the Government of Cilacap Regency and also especially the local people affected.

Many of the recommendations resulting from this Social Mapping result, for example, pay attention to the conditions of the people who are in Pertamina's Ring 1. In addition, the resulting programs are able to improve the living standards of Cilacap residents. Then the thematic programs following the national holiday are also able to be superior in carrying out CSR activities in the community.

\section{DISCUSSION}

From the problems that have been submitted, and also recommendations from the results of the social mapping conducted by UGM, the management of Pertamina RU IV is engaged in conducting social activities that have an impact on the lives of the people of Cilacap as can be seen in the following table:

\begin{tabular}{|c|c|c|c|c|}
\hline NO & LIST OF ASSISTANCE & PROGRAM & AMOUNT (Rp) & RECIPIENTS \\
\hline 1 & $\begin{array}{l}\text { Construction of } 60 \text { Non-Livable Houses in } \\
\text { Cilacap Regency }\end{array}$ & $\begin{array}{l}\text { Development of Facilities } \\
\text { and Infrastructure }\end{array}$ & 900.000 .000 & $\begin{array}{l}\text { Through the Cilacap district } \\
\text { government and RTLH } \\
\text { community groups }\end{array}$ \\
\hline 2 & $\begin{array}{l}\text { Assistance for Renovation of Multipurpose } \\
\text { Buildings in Village Donan Cilacap }\end{array}$ & $\begin{array}{l}\text { Development of Facilities } \\
\text { and Infrastructure }\end{array}$ & 220.000 .000 & $\begin{array}{l}\text { Through the Cilacap district } \\
\text { government }\end{array}$ \\
\hline 3 & Garbage Dump & Environment & 25.000 .000 & Village Lomanis \\
\hline 4 & Free treatment program in Cilacap District & Healthy & 70.000 .000 & Sub District Cilacap \\
\hline 5 & Construction of a mosque in the village of Kutaw: & Place of worship & 30.000 .000 & Sub District Cilacap \\
\hline 6 & Mangrove tree planting in Segara puppies Cilaca & Environment & 50.000 .000 & Sub District Kampung Laut \\
\hline
\end{tabular}

Table 1:- List of Assistance PT. Pertamina RU IV Cilacap (2019)

Source : Internal data of PT. Pertamina RU IV Cilacap

The table mentions assistance given to the people of Cilacap as a result of the refinery's operational activities. The assistance provided is not merely because they are forced to, but rather looks at the needs of the people in their respective regions.

From the social activities carried out by PT Pertamina RU IV Cilacap, the following results can be documented: 


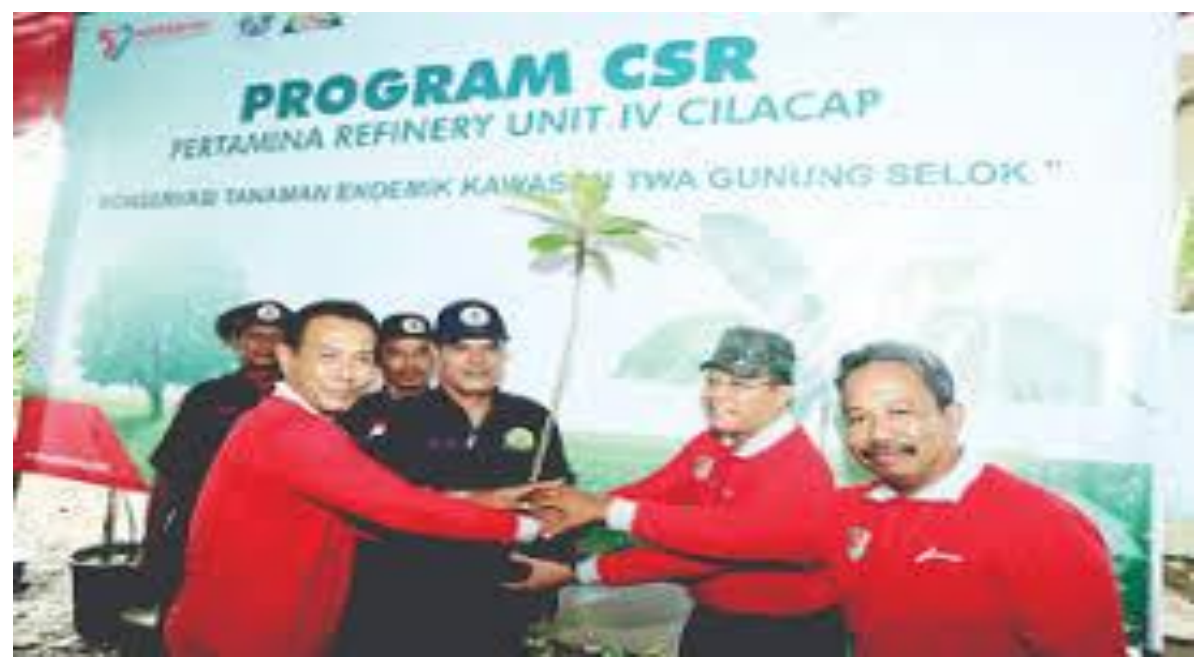

Fig 1:- Assistance for Mangrove Seedlings

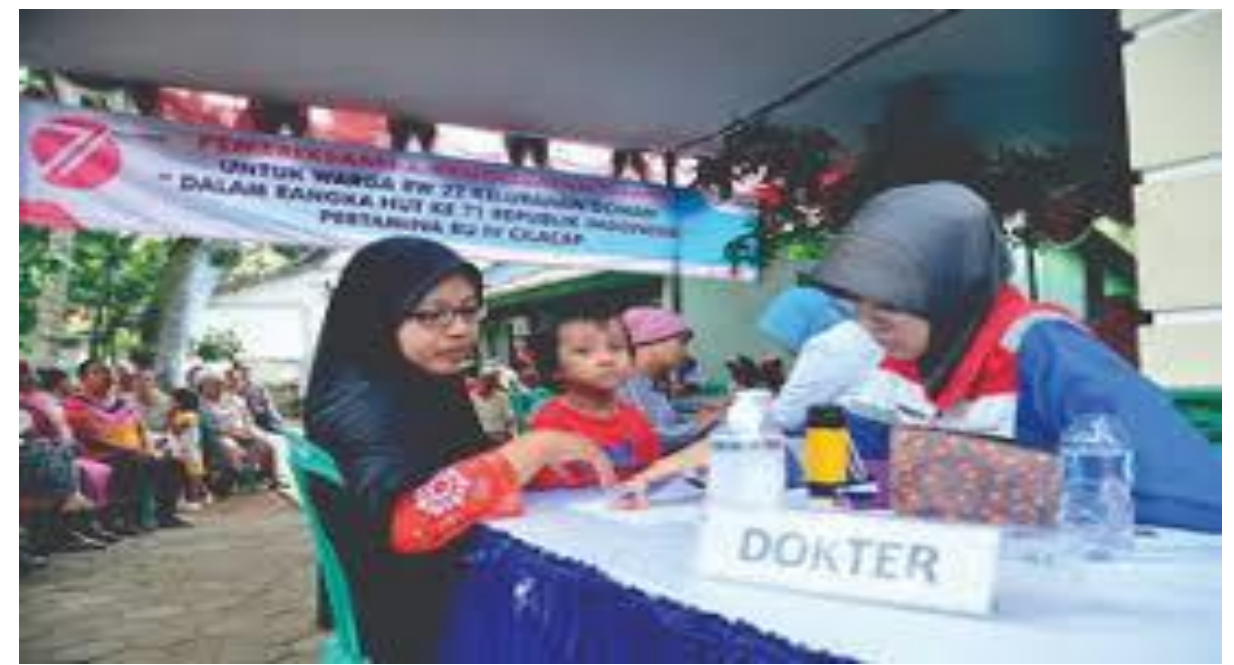

Fig 2:- Free Medical Assistance

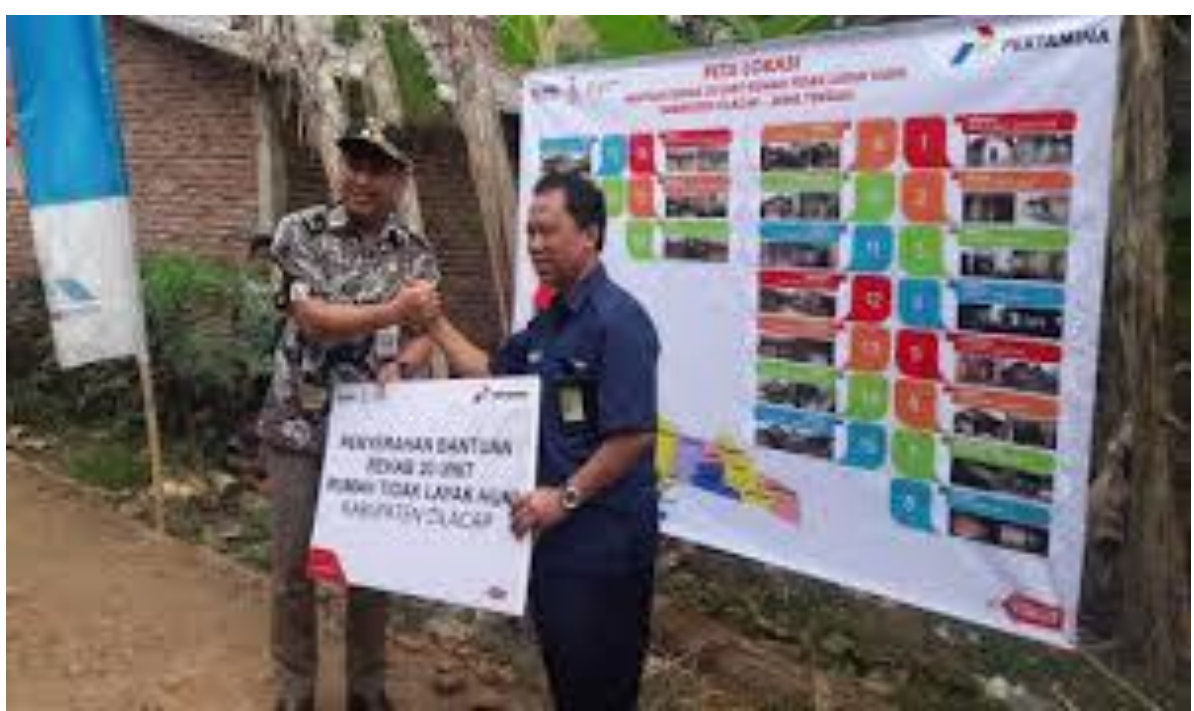

Fig 3:- Assistance fot Construction Livable House 
ISSN No:-2456-2165

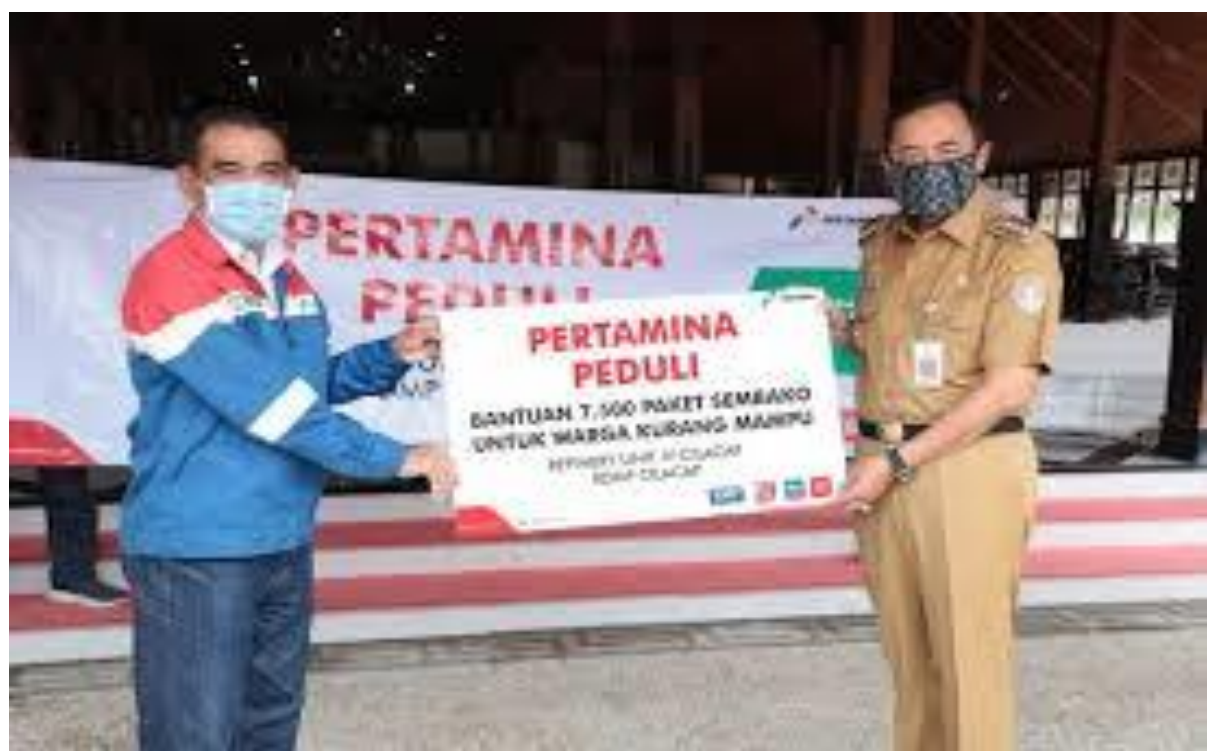

Fig 4:- Assistance Food Packages

Not only in the form of physical assistance given to the surrounding community, but also attention and sympathy if there are people around who died, usually from the Public Relations section to come to the house of citizens to mourn condolences and give a little donation of condolence. Not only in an atmosphere of grief, this is also done in the wedding party of residents around the refinery. This means that companies, both joy and sorrow, feel the conditions of what is happening in the community.

From the results of the research above, it was found that the implementation of CSR in PT Pertamina RU IV Cilacap has been carried out as one of the strategies in maintaining good relations with stakeholders for the sustainability of the company's operational business

\section{CONCLUSION}

The conclusion of these problems is PT. Pertamina RU IV Cilacap has been able to maintain a good relationship between stakeholders, which is shown in the assistance activities provided to affected communities, so that the community really feels the presence of the company. The strategy of implementing Corporate Social Responsibility is able to produce programs that benefit the company and surrounding communities.

The suggestion for PT Pertamina RU IV Cilacap in the future is for assistance to be given not only for donations but also for sustainable living such as increasing MSMEs as a community foundation to improve business results in order to obtain sufficient income. Then to increase tourism as one of the region's original revenues, Cilacap has a lot of attractive tourism potential, this can be collaborated with the Company. Examples such as mangrove tourism areas that are not much touched, even though it could be developed into one of the leading tourist destinations because it has extensive mangrove forests and various types of mangroves in Indonesia.

\section{REFERENCES}

[1]. Setyo Riyanto, Eny Ariyanto and Lukertina. (2019), Work Life balance and its Influence on Employee Engagement "Y" Generation in Courier Service Industry. International Review of Management and Marketing, Vol 9, Issue 6.

[2]. Setyo Riyanto and Lukertina. (2019), " Does the Good Corporate Governance Culture Good for Workers?". IOSR Journal of Business and Management (IOSRJBM), Vol. 21, No. 8, 2019, pp. -..15-20

[3]. Suharto, Edi (2007a), Pekerjaan Sosial di Dunia Industri: Memperkuat Tanggungjawab Sosial Perusahaan (Corporate Social Responsibility), Bandung: Refika Aditama Anderson, B. (1983). Imagined communities. London: Verso.

[4]. Widjaja, Gunawan, dan Yeremia Ardi Pratama, (2008), Seri Pemahaman Perseroan Terbatas Risiko hukum \& Bisnis Perusahaan Tanpa CSR, Jakarta: Forum Sahabat 